\title{
Addiction and depression comorbidity approaches
}

\author{
Katarina B. Crnić ${ }^{1}$, Mirjana M. Todorović 2 , Srdjan Z. Marković 3 , \\ Dragana A. Kastratović ${ }^{3}$, Ivana P. Timotijević ${ }^{4}$ \\ ${ }^{1}$ Specialised hospital for addiction disorders, Belgrade, Serbia \\ ${ }^{2}$ Specialised psychiatric private practice „Ramah“, Belgrade, Serbia \\ ${ }^{3}$ Clinical Centre of Sebia, Belgrade, Serbia \\ ${ }^{4}$ General hospital „Euromedic“, Belgrade, Serbia
}

\section{SUMMARY}

Topic: Comorbidities, simultaneous occurrence of two or more disorders are common in psychiatry; therefore the concept of dual diagnosis was established due to new ethiopatogenetic dilemmas and principles of diagnosis and treatment of these conditions. The most common are comorbid affective disorders and comorbidity of drug addictions and affective disorders.

Topic position in medical public: Epidemiological studies show a high percentage of comorbidity of drug addictions and depression. Various studies show that about one-third of individuals with depression have addiction, and often some other psychiatric disorders are present, such as personality disorder, anxiety, and bipolar affective disorder. Comorbid disorders exacerbate one another; have tendencies to chronicity and treatment resistance. The problem of adequate diagnosis is common; other diagnosis is neglected, leading to inadequate treatment and poor outcomes. Researches of possible causes of addiction and depression comorbidity follow different theoretical assumptions. One favor genetically determined vulnerability, the others are addressing to the impact of trauma in the formative stages of personality development. Widespread is the theoretical assumption on the deficit functioning of the same regions of the CNS and the same neurotransmitters system. In previous studies the preclinical ones dominate, which are theoretically placed in the context of the CNS of a man. Most of the research are related to dysfunction of the serotonergic and dopaminergic systems, whose influence on addiction and depression are clear, and recent studies show the importance of neuromodulators and their receptors, for example, the role of natural opioid dynorphin and "kappa" receptors in the mesolimbic reward system.

Further action: The better diagnosis would require proper screening of patients entering addiction treatments for affective disorders and vice versa. Treatment have to be combined; in addition to medications for addiction essential are antidepressants, atypical antipsychotics, and/or mood stabilizers, for better therapeutic results.

Keywords: addiction, depression, comorbidity, dopamin, serotonin, reward 


\section{TOPIC}

Comorbidity is defined as the simultaneous occurrence of two or more different diagnostic disorders/diseases. In psychiatry, comorbidity is very clear phenomenon. Comorbidity within the affective disorders is best known (e.g. anxiety, depressive disorders), comorbidity of substance abuse and affective disorders [1].

Epidemiologic researches have shown importance of comorbidity disorders and have stimulated new researches, which aimed to provide answers not only in defining the scope but etiopathogenesis and diagnostics as well, especially after the establishment of the concept of so-called dual diagnosis. The term dual diagnosis is related to comorbid occurrence of substance abuse and other psychiatric disorders, in which depression is represented in percentages at most [1].

General characteristics of the comorbid disorders psychiatry are that they degenerate each other, aiming at chronicity courses and treatment resistance. The data shows increased suicidal risk and aggressive behavior for these patients. Another diagnosis is often overlooked, emphasizing bad outcomes and ineffective treatment [1].

\section{TOPIC POSITION IN MEDICAL PUBLIC}

Addictions and depression are known as chronic and recurrent disorders, often with devastating consequences for the individual and their social surrounding. Chronical exposure to psychoactive substances (PAS) and the later stages of abstinence are closely associated with anxiety and depression. Depression and its symptoms in some individuals are a potential risk for abuse of PAS in order to treating with self- medication, and often the risk of developing addiction] [2].

These facts require improvements of diagnosis and understanding of the etiopathogenetic mechanism of these comorbid disorders that would lead to more effective methods of treatment.

Epidemiological data on comorbid addiction and other mental disorders

The high prevalence of comorbidity between drug addictions and other mental disorders has attracted attention with results of outstanding national epidemiological studies in the US, published in the 1990.

It is estimated that $45 \%$ of persons with alcoholic addiction and $72 \%$ of the drug addiction has at least one comorbid psychiatric disorder [3,4]. Gender differences also have an impact. According to the results of these studies, men as alcoholic addicts suffer from depression three times more than general population, while for females addicted to alcohol, that percentage is four times higher. In female population, addiction and affective disorders were often comorbid, while in male population, addiction was combined with attention deficit hyperactivity disorders [5].

Epidemiological Clinical studies in samples of the general population have also pointed to the high percentage of affective disorder importance and dependence on psychoactive substances. Therefore, other psychiatric disorders may be indicated, such as bipolar affective disorder or Attention Deficit Hyperactivity Disorder, ADHD [6]. Results of comorbidity assessment vary in studies. There is for example, $15-67 \%$ prevalence of depressive disorder in alcoholic addicts requiring treatment, or $16-75 \%$ in opiate addicts [7]. Studies that have examined the comorbidity in a population of depressed patients indicated the presence of addiction in almost $1 / 3$ of the examined subjects [8].

\section{Ethiopatogenic comorbidity assumptions of substance abuse and depression}

Considering that results of the epidemiological studies mainly pointed to comorbidity of substance abuse and affective disorder importance, especially depression, numerous researches are still dealing with the associated cause of these disorders. First of all, existing issue should be resolved-whether addiction on substances in their courses contributes to the development of various different risk factors for other mental disorders and vice versa, or if it is common basis or complex influence of genetic, developmental and neurobiological mechanisms for both types of disorder. It is clear that the development of the concept of dual diagnosis suggests that common basis point of view is prevailing, supported by the findings preclinical and clinical studies [9, $10]$.

\section{Genetic comorbity theories}

Genetic theories of comorbidity resulted from pre-clinical trials, with conclusions obtained 
from experiments on animals, theoretically passed on to human subjects. Mostly, it is about searching for genes that may increase the predisposition of the individual for developing both disorders. It is expressed that it concerns increased vulnerability, resulting from complex reaction of multiple genes and outer surrounding factors. However, this may concern direct influence of genetic and epigenetic changes in the transcription factors or enzymes within the central nervous system (CNS) and the neurotransmitter system dysfunction, leading to variability in individual reactions to psychoactive substances or stress. The influence may as well be indirect, through the development of certain dimensions of personality (novelty seeking, risk taking) leading individual to risky consumer behavior, for example, contact with PAS or exposure to stress [11]. This mainly concerns researches on receptors, both serotonergic and dopaminergic, given that both addictions and affective disorders are at most associated with dysfunction of these two central neurotransmitter systems of CNS.

Thus, for instance, Delta FosB protein research, transcription factor for genes producing dopamine and serotonin and its connection with the serotonin $1 \mathrm{~B}$ receptor led to the theory of the causal connection between various forms of addiction (from PAS and natural stimuli) and depression with their expression, or stimulation[12]. Removing the serotonin $1 \mathrm{~B}$ receptor in the experiment led to an intensified expression of Delta FosB in nucleus accumbens and to releasing multiple amounts of dopamine in the Ventral Tagmental Area (VTA), leading to addictive consumer behavior of experimental animals. At the same time, there was a fall in the level of serotonin in limbic structures and the prefrontal cortex (PFC). Consequent cascade of neurochemical processes leads to pathological neuroplasticity and fixing reaction patterns within the reward system. Taking into concern the fact that there are animals named as "natural born addicts" lacking B1 serotonin receptors, it was theorized about the various similar occurrences in people with increased genetic vulnerability to addiction and depression [13].

Researching CREB (CyclicAMP response element binding) of transcription factor in neurons of nucleus accumbens, important for producing dynorphin, blocking the kappa opioid receptor (KOR), acting as inhibi- tory control on dopamine releasing and thus balancing reward system has also referred to the connection of addiction and depression. Balanced disorder of this factor's depression, present in the mutated form of CREB in experimental animals, and consequently, dysfunction of kappa receptor, analogically could lead to addictive behavior and/or depression in humans [14].

\section{Developing theories of comorbidity}

Developing theories of comorbidity are based on the significant exchange rate influence on outer surrounding factors, especially on stress and/or trauma in the formative stages of individual development.

It is known that there is high frequency of initial addiction stage and depression during adolescence. Structural and functional changes in the CNS adolescence, with the influence of psychosocial and environmental factors may contribute to vulnerability for individual or comorbid developing of addictions and affective disorders. Moreover, early abuse of the PAS, affecting the encephalic functions in the development such as learning, decision making, behavioral and social control represents significant risk factor for the later development of substance abuse and other mental disorders (1].

The study examining the high prevalence of substance abuse in the population of depressed adolescents concluded the connection between stressful life events, increased activities of hypothalamus-pituitary-adrenal (HPA) axis, increased cortisol levels and their impact on vulnerability for the development of comorbid depression and addiction [15].

\section{Neuro-biochemical comorbidity bases}

Addiction and depression are usually referred to as diseases of reward CNS system, highlighting the similarity between brain regions and neuro-biochemical pathways, as a basic pathophysiologic mechanism for both types of disorders [16].

Fact is that the reward system CNS includes a number of brain structures, starting from lower structures such as VTA and nucleus accumbens in medulla oblongata across the basal ganglia, the thalamus and limbic structures to the prefrontal region of cerebral cortex (PFC) connected by up-regulating and downregulating pathways. All types of monoamines have transmitting function within them, es- 
pecially dopamine, serotonin and noradrenaline, in the mutual dynamic balance including a neuromodulatory system of natural opioids and their receptors. Their activators are all kinds of natural stimuli (food, sex, physical activity of, that the artistic experience), and psychoactive substances, and stress is very powerful activator.

Over the last few decades numerous researches were dedicated to shedding light on one of the roles of neurotransmitters and their receptors in the comorbidity of substance abuse and affective disorder importance, especially depression [16].

The role of dopaminergic system is most researched. Dysfunction of dopaminergic system leads to the development of addictive behavior, having a significant role and meaning in the development of a particular cluster of symptoms in depressive disorder.

It is known that the levels of dopamine in the VTA region grow at acute PAS intoxication, stimulating limbic structures via n.accumbens primarily via neural network nn.amygdala, where are formed positive emotional experience patterns. The ability to predict satisfaction and craving, at the appearance of associative stimulus activates responsive impulses from neural network to the VTA, rising levels of dopamine and causing impulsive and compulsive behavior for PAS re-consumption. Impact of high cerebral structures is veiled by inhibiting GABA transmission from n. accumbens to PFC via the striatum, globus pallidus and thalamus.

During PAS chronic intoxication, levels of dopamine decline, until the dopamine burn-out, explaining the frequent occurrence of comorbid depression in addicts. The sharp decline in the level of dopamine is also responsible for the occurrence of depressive symptoms in abstinence syndrome.

However, dopamine level decline under the stress influence and clinical depression occurrence, causes loss of pleasure, loss of interest and cognitive dysfunction provoking self - medicating PAS consumption [12].

The role of serotonin and serotonergic receptor is complex, depending on the type of PAS effect on the levels of serotonin in different cerebral regions. Raising serotonin level mostly occurs in acute intoxication and in its drastic decline at abstinence and PAS chronic abuse. Influence on the receptors and their sub-types is obviously different and their ac- tivation can stimulate or inhibit activation of transmitters. Serotonin B1 receptor is mostly researched, having a role of intensifying serotonin effect and inhibiting functioning of dopamine in the acute intoxication, while in chronic consumption of PAS comes to reducing reactivity and decrease of serotonin level, loss of pleasure, regardless to enhancing the activation of dopamine in maintaining already formed neural network addiction [14].

Research focus in the last decade turns to the role of neuromodulatory opioid system as a model for the mechanism of action responsible for the development of addiction and depression.Numerous preclinical studies show kappa opioid receptor and dynorphin, activating opiod as most significant in the regulation of motivational processes, reward mechanism and mood regulation [17].

In addition to the inhibitory effect on dopaminergic system at the VTA and n. accumbens level, the KOR is activated at the level of dorsal raphe nucleus and locus coeruleus via Corticotropin Realising Factor (CRF), released as response to stress, as series of cascading neurochemical reactions lead to activation of the serotonin re-uptake of transporters and serotonin intake in neurons is increased.

At the level of $n$. accumbens and nn. amygdala, similar stress induced evens take place, emphasizing the already installed addictive behavioral patterns. KOR functioning researches at the level of the hypothalamus showed reverse interdependence of Brain deriving neurotrophin factor (BDNF) level and ability to influence the neuroplasticity, or potentiating not only structural but also physiologic changes[17].

The modulation of monoamine pathways at different levels of CNS has important implications for the mood regulation and maintaining addiction in experimental animals. Conclusion states that stress intensifies these effects and stimulates symptoms of both disorders such as craving, relapse with PAS, depressive mood, loss of pleasure and anxiety. In the experiments the use of agonists or antagonists of the KOR have resulted as pro and anti-depressive effect, and weakening of addictive behavior [18].

In addition to preclinical studies, neuroimaging clinical studies started recently and its results shall provide a proof for the existence of these occurrences in humans as well as possibilities for the development of new 
KOR antagonist therapeutic agents [18].

\section{FURTHER ACTION}

The authors insist on the need for improvements of outcomes and therapeutic efficacy in the treatment of patients.

With regard to the diagnostic existing issue and doubt, it is recommended that patients entering addiction treatment shall be screened on affective disorder and vice versa. This is simply achieved by carefully analyzing disease history and applying the existing scale for assessment [19].

It is essential that patients are monitored intensively after curing abstinence syndrome, as most affective disorders develop exactly at that period.

It is necessary to apply an integrative treatment of addictions. In addition to the medications for the treatment of addiction diseases - agonists or antagonists of opioid receptors and other aversive medicaments, specific drugs should be administered for comorbid disorder, provided these drugs show as antidepressants, optionally psychostabilizers or atypical antipsychotics as needed [1].

When affective disorder is primary, sensitivity to the risk of abuse or addiction to PAS, especially to anxiolytics, sedatives, to alcohol and rarely to illicit substances is recommended, especially when there are data in the history of the disease. Also, their parallel treatment is required [19].

In addition to medication, often application and other forms of treatments such as psychotherapy (CBT) and family-therapy are required to achieve remission quality,especially in order to prevent relapse and recurrence as well as changing perspective of disrupted behavior patterns and complete recovery in personal social aspect.

\section{REFERENCES}

1. NIDA Research Report Series Comoridity. US Department of Health and Human Services/ Natuonal Institutes of Health. 2008; 10- 5771.

2. Davis L, Uezato A, Newell LM, Frazier E. Major depression and comorbid substance use disorders. Curr Opin Psychiaty. 2008; 21 (1), 8-14.

3. Robins LN, Regier DA. Psychiatric disorders in America: the Epidemiologic Catchment Area Study. Free Press New York. 1991.

4. Kessler RC, Antony JC, Blazer DG, Bromet E,
Eaton WW, Kendler KS, Swartz M, Wittchen $\mathrm{H}-\mathrm{U}$, Zhao S. The US National Comorbidity Survey: Overview and Future Directions. 1997.

5. Swendsen J, Conway KP, Degenhardt L, Dierker L, Glanez M, Jin R, Merikangas KR, Sampson S, Kessler RC. Sociodemographic risc factors for alcochol and drug dependence: The 10-year follow-up of the National comorbidity survey. Addiction.2009; 104(8), 1346-1355.

6. Kessler RC. The epidemiology of dual diagnosisi. J.of Biological Psychiatry. 2004; 56(10), 730-737.

7. Kessler RC. Comorbidity of unipolar and bipolar depression with other psychiatric disorders in general population survey. In M. Tohen (Ed): Comorbidity in Afective Disorders. New York: Marcel Dekker Inc. 1999;1-25.

8. Merikangas KR, Rajni LM, Molnar BE, Walters EE, Swendsen JD, Aguilar-Gaziola S, Bijl R, Borges G, Caraveo-Andnaga JJ, Dewit DJ, Kolody B, Vega WA, Wittchen $\mathrm{H}-\mathrm{U}$, Kessler RC. Comorbidity of substance use disorders with mood and anxiety disorders: Results of the International Consortiom in Psychiatric Epidemiology (ICPE). Addiction Behaviors. 1998; 23, 893-907.

9. Quelo SB, Brady KT, Sonne SC. Mood disorders and substance abuse disorders: A complex comorbidity. Science\&Practice Perspectives. 2005; 3(1), 13-24.

10. Conway KP, Compton W, Stinson FS, Growt BF. Lifetime comorbidity of DSM-IV mood and anxiety disorders and specific drug use disorders: Results from the National Epidemiologic Survey on Alcochol and Related Conditions. J Clin Psychiatry. 2006; 67(2), 247-257.

11. Uhl GR, Grow RW. The burden of complex genetics in brain disorders. Arch Gen Psychiatry. 2004; 61 (3), 223- 229.

12. Carlezon WA, Pliakas AM, Carlson RR, Neve RL, Nestler EJ. Altered responsivenes to cocaine and increased immobility in the forced swim test associated with elewated cAMPresponce element-binding protein expression in nucleus accumbens. Journal of Neuroscience. 2001; 21, 7397-7403.

13. Paterson NE, Markou A. Animal models and treatments for addiction and depression comorbidity. Neurotox Res. 2007; 11 (1), 1-32.

14. Carlezon WA, Duman RS, Nestler EJ. The many faces of CREB. Trends in Neuroscience. 2005; 28, 436-445.

15. Rao U, Hammen CL, Poland R E. Mechanisms underlying the comorbidity between depressive and addictive disorders in adolescents: Interaction between stres and HPA activity. Am J of Psychiatry. 2009; 166 (3), 361-369.

16. Timotijevic IP, Todorovic MM, Crnic KB, Markovic SZ, Kastratovic DA. Affective Spectrum Disorders and Role og Serotonergic System of the Brain. Hos- 
pital pharmacology - International Multidisciplinary Journal. 2014; 1 (3), 168-173. ( www.hophonline. org )

17. Lalanne L, Ayranci G, Kieffer BL, Lutz P-E. The kappa opioid receptor: from addiction to depression, and back. Front Psychiatry. 2014; 5:170, $1-22$.

18. Carroll FI, Carlezon WA. Development of kappa opioid receptor antagonists. J Med Chem. 2013; 56 (6), 2178- 95.

19. Brady KT, Verdnin ML. Pharmacotherapy of comorbid mood, anxiety and substance abuse disorders. Substance use ans misuse. 2008; 40, 20212024, 2043-2048. 


\section{Aspekti komorbiditeta bolesti zavisnosti i depresije}

Katarina B. Crnić ${ }^{1}$, Mirjana M. Todorović ${ }^{2}$, Srdjan Z. Markovic ${ }^{3}$, Dragana A. Kastratovic ${ }^{3}$, Ivana P. Timotijević ${ }^{4}$

${ }^{1}$ Specijalna bolnica za bolesti zavisnosti, Beograd, Srbija

${ }^{2}$ Specijalistička psihijatrijska ordinacija „Ramah“, Beograd, Srbija

${ }^{3}$ Klinicki centar Srbije , Beograd, Srbija

${ }^{4}$ Opsta bolnica „Euromedik“, Beograd, Srbija

\section{KRATAK SADRŽAJ}

Tema: Komorbiditet, istovremena pojava dva ili više poremećaja, je česta u psihijatriji, a najučestaliji su komorbidni afektivni poremećaji i komorbiditet bolesti zavisnosti i afektivnih poremećaja. To je dovelo do uspostavljanja pojma dualne dijagnoze, uz nove etiopatogenetske dileme i principe dijagnostikovanja i lečenja ovih stanja. Pozicioniranje teme u medicinskoj javnosti: Epidemiološke studije pokazuju visok procenat komorbiditeta bolesti zavisnosti i depresije. Različite studije ukazuju da oko jedne trećine individua sa depresijom ima adikciju, a prisutni su često i drugi psihijatrijski poremećaji, kao poremećaj ličnosti, anksioznost, bipolarni afektivni poremećaj. Komorbidni poremećaji pogoršavaju jedni druge, imaju sklonost ka hronicitetu i teraporezistenciji. Problem adekvatnog dijagnostikovanja je čest, druga dijagnoza se zanemaruje, što vodi ka nedovoljnom tretmanu i lošim ishodima. Istraživanja mogućih uzroka komorbiditeta adikcije i depresije prate različite teoretske postavke. Jedne daju prednost genetski uslovljenoj vulnerabilnosti, druge se bave uticajem traume u formativnim fazama razvoja ličnosti. Najrasprostranjenija je teoretska pretpostavka o deficitu funkcionisanja istih regiona CNS $i$ istih neurotransmiterskih sistema. U dosadašnjim istraživanjima dominiraju pretkliničke studije, čiji se nalazi teoretski stavljaju u kontekst CNS čoveka. Najveći broj istraživanja se odnosi na poremećaje funkcionisanja serotonergičkog i dopaminergičkog sistema, čiji je upliv na adikciju i depresiju jasan, a novija istraživanja govore o značaju neuromodulatora i njihovih i receptora, na pr. uloga prirodnog opioida dinorfina i kappa receptora u mezolimbičkom reward sistemu.

Dalji razvoj: Bolje dijagnostikovanje bi zahtevalo da se pacijenti koji ulaze u tretman adikcije skriniraju i na afektivne poremećaje i obrnuto. Tretman je kombinovan, pored medikacije za bolesti zavisnost neophodni su antidepresivi, atipični antipsihotici ili/i psihostabilizatori, radi boljih terapijskih rezultata.

Ključne reči: adikcija, depresija, komorbiditet, dopamin, serotonin, reward 